Beginning with the summer of 1919 the work of the laboratory will be organized on a research basis, and only those prepared for independent work will be admitted. The laboratory will open June 23, continuing in session ten weeks and closing August 30. Any one interested in the work for the coming summer should address the director, Robert B. Wylie, of the University of Iowa, Iowa City, Iowa.

\section{DISTINGUISHED SERVICE MEDALS}

General Pershing has awarded the Distinguished Service Medal to a number of medical officers including the following:

Francis A. WINTER, Brigadier-General. As chief surgeon of the lines of communication, American Expeditionary Forces, from June to December, 1917, he organized medical units at the base ports and in camps in France. $\mathrm{He}$ established large supply depots from which medical supplies were distributed to the American Expeditionary Forces, and by keen foresight and administrative ability, made these supplies at all times available for our armies.

Joseph A. BlaKe, Colonel. As chief consultant for the district of Paris, and commanding officer of Red Cross Hospital, No. 2, he efficiently standardized surgical procedures especially in the recent methods of treating fractures. His remarkable talent has materially reduced the suffering and loss of life among our wounded.

Grorge W. CrILe, Colonel. By his skill, researches and discoveries, he saved the lives of many of our wounded soldiers. His tireless efforts to devise new methods of itreatment to prevent infection and surgical shock revolutionized Army surgery and met with the greatest success.

WILLIAM H. WILMER, Colonel. As surgeon in charge of medical research laboratories, air service, American Expeditionary Forces, since September, 1918, he has rendered most distinguished service. His thorough knowledge of the psychology of flying officers and the expert tests applied efficiently and intelligently under his direction have done much to decrease the number of accidents at the flying schools in France and have established standards and furnished indications which will be of inestimable value in all future work to determine the qualifications of pilots and observers. The data collected by him is an evidence of his ability, his painstaking care and of his thorough qualifications for the important work intrusted to him. The new methods, instruments and appliances devised under his direction for testing candidates for pilots and observers have attracted the attention and been the subject of enthusiastic comment by officers of the allied services, and will be one of great importance in promoting the safety and more rapid development $0^{\circ}$ aerial navigation.

Joet E. GoLDThwaIT, Colonel. As a member of the medical corps he has, by his unusual foresight and organizing ability, made it possible to reclaim for duty thousands of men suffering from physical defects. He has thereby materially conserved for combat service a great number of men who would have been lost to the service.

Thomas W. Salmon, Colonel. He has, by his constant tireless and conscientious work, as well as by his unusual judgment, done much to conserve manpower for active front line work. He was the first to demonstrate that war neurosis could be treated in advanced sanitary units with greater success than in base hospitals.

\section{SCIENTIFIC NOTES AND NEWS}

JoSEPH BARRELL, professor of structural geology at Yale University, died on May 4 from pneumonia and spinal meningitis, aged forty-nine years.

THe National Research Council announces the appointment of James Rowland Angell, dean of the faculties, and professor of psychology in the University of Chicago, as chairman of the council for the year commencing July 1, 1919. Dr. Angell succeeds Dr. George E. Hale, director of the Mount Wilson Solar Observatory of the Carnegie Institution of Washington, who has directed the affairs of the council during the war, and who resigned as chairman on April 30, to return to California. Dr. John C. Merriam, professor of paleontology in the Univensity of California, who has been acting chairman of the council at various times, will direct its affairs until Dr. Angell assumes office in July.

AT a meeting of the Franklin Institute at Philadelphia on May 21, the presentation of the Franklin Medals will be made to Sir James Dewar, the distinguished English chemist, and to Major-General George Owen Squier, of the 